\title{
Self-Reflection on Critical Theory Course
}

\author{
Sarah Zulkarnaini \\ Department of Early Childhood Education, School of Postgraduate, Universitas Pendidikan Indonesia \\ Corresponding author. Email: sarahz@upi.edu

\begin{abstract}
The purpose of this paper is to describe self-reflection during critical theory classes. A student should have a critical way of thinking. In this paper, the authors describe many new perspectives, especially in thinking, including how politics, society, economy, culture affect human views and activities. The authors concluded that scepticism is necessary in building critical thinking.
\end{abstract}

Keywords: Self-reflectivity, critical theory.

\section{INTRODUCTION}

Continuing postgraduate study and choosing a different major than before is an option with of course consequences. Now, to be precise, I'm going through even semester, with a load of more than my friends who are in the same major, however, I believe this is a challenge and a very meaningful process. One of the courses that provide a lot of new insights in my opinion is the critical theory course. Last semester, this course became the conversation of my friends in regular class every morning, I thought how interesting and dizzy this course is. In fact, I was stunned after attending the first meeting to discuss injustice. Precisely with this course, it makes me feel so narrow the insights I have.

Discussing critical reading gives a big question in my mind, every situation I train myself with asking "why?" As part of the driving force for education, although not in PAUD institutions, I now train myself to see things more flexibly, broadly, and be sceptical of any information I get. The goal is that I am more critical in facing something and consciously or not be able to construct the same understanding of students and the people around me. I think this understanding of "seeing flexibly" is important not only for a master's level student, but it must be able to pass on to society.

\section{NEW UNDERSTANDING}

I have never found an understanding of the truth in question until the first day of the critical theory course taught by Dr Hani Yulindrasari and Dr Vina Adriany introducing critical readings. Her initial introduction gave a different impression when Dr Hani explained that this critical theory actually exposed injustice in early childhood education. One more thing, in my opinion, this is a very meaningful introduction, she also had time to express the side of injustice in which Piaget's cognitive development theory was based on his research on his own children, it can be ascertained that Piaget's upbringing and culture were different from children in other parts of the world, but unfortunately the concept that Piaget initiated become the basis of most parents and early childhood institutions as universal reference for child development. When children are considered not developing according to universalized standards, because their development is different from Piaget's concept, it makes sense to say that the judgement is unfair. Not that the Piaget concept is wrong, but the assumption that the Piaget's concept is universally applicable is wrong.

Interestingly, one of the discussions that made me think that it interfered with the break was about "power relations". Before getting an understanding of power relations, it had occurred to me to continue this study to get a social recognition, where social status would certainly influence the movements or programs that would be offered in society. I hope that with the strength of this social status, it will be easier for me to do da'wah (religious mission) movements. But then I thought it was just my selfishness. Fortunately, I got enlightened in this subject, which turned out to be a theory about power by Foucault. Starting from my assumption that status/power affects the surrounding response to actions, I then realized that in this life, the process of social interaction is very influential. As well as how a person gets privilege from social status, that turns out to be related to the existence of power relations. 


\section{EXPLORE THE GOALS AND FEEL THE BENEFITS}

I see the purpose of studying critical theory is to question a truth, and try to use other glasses such as culture, politics, history, and economics to translate the information obtained. This trains a person to be more flexible in seeing the truth. At first, I had the chance to ask "indeed why with the truth, why should it be a problem so that there is a disagreement by one theory to another?", I can answer that now, because there are many factors that support information which is considered true, so there are groups those who are marginalized and marginalized, there are groups that are disadvantaged, there are groups who feel injustice in their lives, and that is not something that is the goal of life, even in religion. If it is highlighted in the realm of religion, all religions essentially want a peaceful life.

Meanwhile, the purpose of critical thinking from what I understand after reading some critical reading is to assess a thought and to sharpen thinking power, and evaluate the implementation of a thought, not forgetting to see the broader side. If we look at a theory, then we can see inside ourselves, or the current condition. How does this theory affect people's perceptions, or precisely how the theory is forgotten, or maybe not forgotten, but is hidden behind the power relations at play, as stated by Foucault that truth shapes existing power relations [1]. In addition, Foucault said that power is everywhere not because it includes everything, but because power comes from everywhere [2].

I can express this, after I have completed my UTS academic writing assignment, namely making a bibliography. Even to see an article that has been published, we need to know who the author is, his background, his research and so on. This is none other than trying to be critical in taking a reference for our writing. Even to write this goal, I have to reflect on myself to redraw the old experiences that I felt.

Today, social life is increasingly complex, so critical thinking is needed to respond to it all. I see that this course has the potential to give someone a perspective on the truth. There is no absolute truth, including the truth shown by many researchers about the findings. Problems arise when certain governments make it a benchmark. This sometimes has a negative impact on the social life of the community, for example when a policy is enforced uniformly regardless of the background of a region. In general, this is not realized, just lived it. However, by using a critical lens, we can highlight the existing injustices. Another example, to counter the effects of unequal domination by discourse on developmentalism or child centred systems which are considered "truth", teachers can take action with self-liberation from this absolute understanding, this is expressed in Mac
Naughton's reading [2]. Every early childhood educator should find this reading.

\section{FINDING NEW INSIGHTS AS CAPITAL}

On one occasion, I tried to understand one postmodern view, when we need to be more aware of how language shapes what we see, feel, and believe. In reading materials provided by lecturers, I found discussions related to communication and gender. Interestingly, this discussion is in accordance with the discussion of the thesis that I plan to adopt, so I feel this is very helpful for broadening my horizons.

My desire to research gender and communication stems from my reflections on a few years ago. I see and feel it myself, when teaching usually relies on existing experiences, even though it is known that when being a teacher in the class it is better to communicate appropriately to achieve learning goals, which is able to motivate students, give clear directions to students, construct understanding and so on. No matter how good a model, strategy or approach is if the teacher is not good at communicating, it could be that the goal is not optimal. This is a picture of my anxiety regarding communication. Unfortunately, this is just my assumption which is not based on anything. However, when studying critical theory, I find support for this assumption, as Gupta [3] explains that language plays a critical role and plays an important role in the construction of knowledge and meaning. It is clear that language here is part of communication, so this theory can be a supporting asset in my later thesis research.

It is also supported by Alloway's explanation that physical interactions between organisms and the environment through the process of assimilation and accommodation can block the influence of social, cultural and historical factors (ways of interacting with people, language, traditions and rituals) on children's learning and cognitive development [4]. Another example such as Vygotsky's view of the construction of knowledge becomes not only cognitive but also social. Likewise, the way of thinking and interpreting the world is closely related to social and language interactions [3].

In addition, the translation of the knowledge that is built up is then transferred to the children through dialogue, this reflects the communication-construction process. Supported by the existence of a social script informs the experience of each child in many ways with cultural tools (such as language), symbols, habits, food, and the use of space in general [5]. Their activities highlight 'ever-existing memories' of gender in children's lives and its effect on how children establish relationships, rituals and routines in everyday life [2].

The idea of this problem originated when I found a moment with my child, when a neighbour asked my child to chat, and he asked questions about activities, came to 
the question of who cooks, who accompanied him to sleep and several other questions. My child's answer to almost all questions is "father and mother", simply, I interpret that my child understands that the activity being asked is not an absolute job of his father or mother, but the responsibility of both because he sees it as such. But I think it would be a different answer if what he saw his mother cooking every day, then he would construct his understanding that cooking is a woman's job. This is where my belief raises the gender construction of a communication. It is an interesting analysis in my opinion when looking at the communication that has been built by adults with children regarding gender.

\section{CONCLUSION}

After trying to recall experiences in my life, I began to see the connection between old memory and new learning after studying in a critical theory course. I remember my parents often giving advice about living a peaceful and sensitive life towards others. When I reflect on this course, I find the intersection of the concept of critical thinking by being sensitive to others. We may be fine, but not necessarily other people feel the same way as us, and that we need to explore to try to be fair.

Students generally experience some difficulties, especially as beginners in reading critical theories, as well as me. However, this difficulty actually becomes a challenge in itself that raises higher morale. Among the challenges faced were: (1) limited English which made it difficult for me to understand the meaning of the reading; (2) each individual certainly has an understanding of knowledge that has been constructed beforehand, when reading a critical theory, the mind is like discussing one another, due to the frequent emergence of two understandings that are not necessarily in line with oneself; and (3) insights that are still very narrow, sometimes making it difficult to find similar examples in life, as a result the theory is not remembered strongly or its essence is poorly understood.

\section{REFERENCES}

[1] Keohane K. City life and the conditions of possibility of an ideology-proof subject. In: Malesevic S, MacKenzie, editors. Ideology after Poststructuralism. London: Pluto Press; 2002. pp.6484.

[2] MacNaughton G. Doing Foucault in early childhood studies: Applying post-structural ideas. New York: Routledge; 2005.

[3] Gupta A. Early childhood education, postcolonial theory, and teaching practices in India. New York: Palgrave Macmillan; 2006.

[4] Alloway N. Early Childhood Education Encounters the Postmodern: What do we know? What can we count as 'True'? Australasian Journal of Early Childhood. 1997;22(2):1-5. Available from: https://doi.org/10.1177/183693919702200202.

[5] Krieg S. To teach or not to teach in the early years: What does this mean in early childhood education. In Early Childhood Education. In: Donna FS, editor. Early Childhood Education. London: IntechOpen. pp.69-79. 